\title{
Analisis Isi Objektivitas Berita Operasi Tangkap Tangan Walikota Kendari dan Asrun di Harian Kendari Pos, Rakyat Sultra dan Berita Kota Kendari
}

\author{
Suwardi Thahir \\ Univeritas FAJAR (UNIFA) Makassar
}

Suwardithahir17@gmail.com

\begin{abstract}
Abstrak
Pemilihan kepala daerah (Pilkada) secara langsung membawa kebaruan dalam berdemokrasi. Namun dalam pelaksanaan sistem yang menganut one man one vote one values ini memerlukan biaya besar dengan konsekuensi kalah dan menang tak terprediksi. Pilkada yang sejatinya menjadi ajang pesta demokrasi bagi konstestan yang akan bertarung, berubah menjadi arena penangkapan sejumlah calon peserta Pilkada karena terlibat suap biaya pemenangan. Walikota Kendari, Adriatma Dwi Putra dan Asrun, ayahnya terjaring Operasi Tangkap Tangan (OTT) Komisi Pemberantasan Korupsi (KPK) pada 27 Februari 2018, kemudian tersangka karena suap proyek. OTT ADP dan Asrun menjadi liputan utama suratkabar Kendari pos, Rakyat Sultra dan Berita Kota Kendari (BKK) yang selama ini memiliki kedekatan dengan tersangka, sehingga bisa memengaruhi isi berita. Penelitian ini bertujuan melihat Objektivitas Berita Operasi Tangkap Tangan Walikota Kendari Adriatma Dwi Putra dan Asrun. Penelitian ini menggunakan berita halaman satu ketiga media, edisi tanggal 1, 2, dan 3 Maret 2018 sebagai sumber data utama untuk mengetahui objektivitas berdasarkan rumusan Westertahl. Hasil penelitian menunjukkan ketiga media menyajikan berita tanpa melebih-lebihkan fakta, sementara Kendari Pos cenderung memberi penilaian dengan relevansi yang rendah dengan khalayak. Penyajian fakta-fakta berita Rakyat Sultra masih kurang dan penelitian menemukan fakta bahwa nilai objektivitas Berita Kota Kendari di atas kedua media.
\end{abstract}

Kata kunci: Pilkada, Walikota Kendari, Kendari Pos, Rakyat Sultra, Berita Kota Kendari

\section{PENDAHULUAN}

Tahun 2018 disebut sebagai tahun politik. Di seluruh Indonesia, tahun politik ini akan dilalui dengan Pemilihan Kepala Daerah (Pilkada) Serentak sebanyak 171 pemilihan, yang akan memilih 17 gubernur, 39 walikota dan 115 bupati pada 27 Juni 2018. Menyusul Pemilihan Presiden (Pilpres) dan Pemilihan Calon Legislatif (Pilcaleg) pada 2019. Kerasnya persaingan untuk memenangkan kontestasi Pilkada, Pilcaleg dan Pilpres semakin terasa pada awal 2018. 
Selain digelari tahun politik, selama periode Januari-Februari 2018 Komisi Pemberantasan Korupsi (KPK) telah menangkap Walikota Kendari, Adriatma Dwi Putra (ADP) dan empat calon peserta Pilkada lainnya. Walikota Kendari yang baru menjabat lima bulan tertangkap bersama Calon Gubernur Sulawesi Tenggara, Asrun (ASR) yang juga ayahnya, pada 27 Februari 2018 terkait pencalonan Asrun menjadi Gubernur. ADP dan Asrun (mantan walikota Kendari dua periode) menjadi tersangka kasus suap pengadaan barang dan jasa di Pemerintah Kota Kendari bersama Fatmawati Faqih, mantan Kepala Badan Pengelola Keuangan dan Aset Daerah (BPKAD), dan Hasmun Hamzah, pengusaha. Tiga calon peserta Pilkada yang ditangkap sebelumnya adalah Nyono Suharli (Bupati Jombang), Marianus Sae (Bupati Ngada, NTT), Imas Aryumningsih (Bupati Subang). Mereka terlibat sogok-menyogok dalam kaitan penguatan modal untuk ongkos Pilkada.

Hal tersebut sangat berbeda dengan zaman orde baru dimana pemilihan kepala daerah ditentukan oleh rezim penguasa yang memilih pimpinan cukup dengan "penunjukan" langsung kemudian disahkan DPRD. Dulu, penentuan pimpinan model zaman orde baru ini biasa disebut jalur A, B, dan G, yakni pengangkatan pemimpin daerah, bupati, walikota dan gubernur dari Angkatan Bersenjata Republik Indonesia (ABRI), Birokrasi dan Golkar (Partai Golongan Karya).Golkar adalah organ politik atau partai pemerintah yang merupakan representasi penguasa.Reformasi kemudian memaksa penguasa Orde Baru meletakkan kekuasaan dan mengubah sistem penentuan pemimpin lewat jalur A,B, dan G, menjadi pemilihan secara langsung yang melibatkan masyarakat sebagai pemilih sekaligus menjadi penentu kemenangan. Pemilihan secara langsung yang memberi kesempatan berdemokrasi seluas-luasnya kepada masyarakat menyebabkan calon pemimpin yang akan bertarung harus memenangkan hati rakyat agar masyarakat sebagai konstituen memilihnya.

Sayangnya, implementasi sistem demokrasi ini menimbulkan sikap dan pelaksanaan yang boros di lapangan. Ongkos politik yang ditimbulkannya menjadi tinggi atau bahkan tak terduga. Upaya memenangkan pemilihan disikapi dengan cara-cara yang tak sesuai ukuran ekonomi, efektif dan efisien. Untuk ikut kontestasi mereka harus merogoh kantong lebih dalam untuk biaya sosialisasi, biaya transportasi, biaya logistik dan ongkos-ongkos lain sebelum sampai pada hari pemilihan.

Di samping membawa warna demokrasi, reformasi juga memberi kebebasan yang luas terhadap arus informasi. Media massa yang terpasung di zaman orde baru menemukan momentum untuk bebas dari segala belenggu. Media massa atau pers menikmati kebebasannya yang mereka istilahkan kemerdekaan pers. Pers betul-betul ingin menjadi pilar demokrasi keempat, setelah yudikatif, legislatif dan eksekutif.

Di dalam analisis media, asumsi dasar yang berlaku pada semua teori tentang perkembangan pers, yaitu bahwa institusi pers diwarnai oleh sistem poilitik dimana pers itu lahir dan berkembang. Dalam hal ini, menurut Siebert pers selalu mengambil bentuk dan warna struktur-struktur sosial politik di dalam mana pers beroperasi. Dengan perkataan lain, setiap sistem politik akan memberikan warna tersendiri bagi institusi pers, sehingga setiap perubahan politik akan melahirkan perubahan pada pers sebagai lembaga. (Arifin, 2010: 
8).Demokrasi yang lahir dari rahim reformasi ini membawa peran pers dalam kehidupan sosial politik semakin menonjol dan pers bermetamorfosis dari institusi yang menonjolkan idealisme menjadi institusi berpostur komersial. Perusahaan pers menjadi akrab dan dibutuhkan oleh politisi karena media berperan dalam menonjolkan atau meredupkan ketenaran.Media bisa menjadi pendongkrak popularitas dan tingkat keterpilihan.

Memasuki tahun politik, para konstestan yang memiliki kedekatan dengan kekuasaan atau birokrasi akan menggunakan daya yang tersedia untuk memenangkan pemilihan. Segala cara atau menghalalkan segala cara kemudian menjadi jalan pintas yang bisa ditempuh. Sogok-menyogok atau membiayai kebutuhan kandidat yang dijagokan menjadi kelaziman yang pembuktiannya gampang-gampang susah. Komisi Pemberantasan Korupsi akhirnya menangkap sejumlah pejabat, birokrasi, politisi, penegak hukum dan pengusaha yang disangka melakukan perbuatan sogok, kegiatan transaksional yang disertai janji, atau menangkap pelaku secara langsung dalam Operasi Tangkap Tangan (OTT) seperti yang dialami ADP dan Asrun. Penangkapan keduanya sekaitan dengan penerimaan uang untuk biaya pemenangan Pilkada Asrun.

Penangkapan pejabat dan mantan pejabat walikota yang selama ini menjadi mitra media lokal di Kendari langsung muncul menjadi berita utama di media nasional, seperti Kompas, Jawa Pos, dan Rebublika, serta media lokal, di antaranya Harian Kendari Pos, Rakyat Sultra dan Berita Kota Kendari (BKM). Ketiga media lokal menganggap berita ini penting sehingga dipasang di halaman satu yang disertai dengan foto.Kedekatan media dengan birokrat yang juga politisi dalam bentuk sponsorhip atau iklan ditengarai akan memengaruhi kualitas pemberitaan. Bahkan pada tingkat tertentu, seperti halnya yang dialami ADP dan Asrun, media akan cenderung terpengaruh lantas meninggalkan objektivitasnya. Suratkabar Kendari Pos, Rakyat Sultra dan Berita Kota Kendari adalah media utama di Sulawesi Tenggara (Sultra) yang memiliki kedekatan dengan Walikota Kendari Adriatma dan Asrun.

Ketiga perusahaan media tersebut induknya dimiliki oleh PT. Media Fajar, kelompok usaha media yang menyebar di wilayah Indonesia Timur. Di Sulawesi Tenggara, group ini juga memiliki Kolaka Pos, Radar Buton dan Sultra TV, di samping memiliki dua mesin percetakan koran. Bertumbuh pesatnya group ini berarti secara sosilogis telah mendapati kepercayaan masyarakat sehingga topik yang menjadi berita halaman satu pemberitaannya dapat memengaruhi opini publik. Topik yang menjadi berita utama suratkabar selain menggambarkan penting dan sedang menjadi perhatian masyarakat, headline dan beritaberita lain di halaman satu adalah identitas yang berguna menolong pembaca agar segera mengetahui peristiwa yang akan diberitakan. Di samping itu, dapat digunakan untuk menonjolkan suatu berita dengan dukungan teknik grafika. (Inung Cahya, 2012: 19).

Pada saat teradinya penangkapan ADP dan Asrun, selama tiga hari, ketiga surat kabar tersebut menyiarkan penangkapan Walikota Kendari Adriatma Dwi Putra dan Asrun yang terjaring OTT oleh KPK sebagai berita di halaman satu. Ketiga media berusaha menyajikan OTT walikota dan Asrun berdasarkan kebijakan redaksional untuk memberi jawaban atas keingintahuan pembaca. Kendari Pos, Rakyat Sultra dan Berita Kota Kendari berusaha 
merekonstruksi realitas empiris OTT menjadi informasi bernilai berita yang layak disiarkan. Campur tangan redaksi, dalam hal ini reporter, redaktur dan bagian grafis terhadap realitas empiris yang terjadi di masyarakat pada dasarnya akan menjadi realitas kedua ketika peristiwa yang terjadi sudah berbentuk berita. Dalam proses ini bisa terjadi penghalusan, penonjolan atau penyembunyian fakta. Berita OTT ini menjadi penting karena mereka yang tertangkap adalah birokrat, politisi dan pengusaha yang berhubungan secara profesional maupun personal dengan pengelola ketiga media. Objektivitas pemberitaan OTT ini menjadi ujian dalam menegakkan prinsip-prinsip jurnalisme, faktualitas dan imparsialitas.

Penerapan objektivitas dalam berita politik dan kasus korupsi yang ditangani KPK ini sangat penting, apalagi bila kedua hal tersebut dikaitkan dengan opini publik. Sebuah berita dikatakan objektif bila memenuhi beberapa unsur, seperti yang dirumuskan Westertahl (dikutip dari McQuail, 1992) yang membagi objektivitas dalam dua prinsip utama, yaitu sesuai kenyataan (factuality) dan tidak memihak (impartiality). (Eriyanto, 2003: 194). Faktualitas berkaitan dengan dimensi kualitas informasi dari suatu berita, sedang imparsialitas merupakan dimensi yang berkaitan dengan sikap tidak berpihak. Apakah suatu berita secara sistematis atau tidak, menampilkan satu sisi atau dua sisi dari suatu isu atau peristiwa yang diberitakan. Objektivitas, dengan demikian dapat didekati dengan melihat dua dimensi, yakni sejauhmana kualitas informasi dan apakah semua sisi dari perdebatan dan peristiwa telah diberitakan oleh media.

Pada skema Objektivitas Westertahl, dimensi faktualitas diturunkan menjadi dua subdimensi, pertama, benar (truth). Sejauhmana berita menyajikan informasi yang benar. Subdimensi ini dapat diturunkan ke subdimensi yang lebih kecil lagi, yakni faktualitas (pemisahan fakta dan opini, komentar, interpretasi), akurasi (kesesuaian dengan fakta atau peristiwa yang sebenarnya), dan lengkap (semua fakta dan peristiwa telah diberitakan seluruhnya). Kedua, relevan. Apakah informasi yang disajikan dalam berita relevan atau tidak. Relevansi ini dapat diturunkan ke dalam subdimensi yang lebih kecil, yakni normatif (relevansi dengan keyakinan umum); jurnalistik (relevansi sesuai dengan kesepakatan dan kebiasaan yang diterima oleh komunitas jurnalistik); khalayak (relevansi dari kacamata khalayak); dan dunia realitas. Sementara dimensi imparsialitas berkaitan dengan apakah berita telah menyajikan secara adil semua sisi dari peristiwa dan perdebatan yang diberitakan. Dimensi ini dapat diturunkan ke dalam dua subdimensi. Pertama, berimbang (balance). Berita yang berimbang adalah berita yang menampilkan semua sisi, tidak menghilangkan (omission) dan menyeleksi sisi tertentu untuk diberitakan.Subdimensi berimbang (balance) ini dapat diturunkan lagi ke dalam unit yang lebih kecil, yakni akses proporsional (apakah masing-masing pihak dan sisi telah diberikan kesempatan yang sama) dan dua sisi (apakah masing-masing perdebatan telah disajikan). Kedua, netral. Berita menyampaikan peristiwa dan fakta apa adanya, tidak memihak pada sisi dari peristiwa. Subdimensi ini juga dapat diturunkan ke dalam sub yang lebih kecil, yakni non-evaluatif (berita tidak memberikan penilaian atau judgment) dan non-sensasional (berita tidak melebih-lebihkan fakta yang diberitakan). 
Berdasarkan pemaparan tersebut di atas, maka penulis tertarik untuk mengkaji lebih dalam mengenai objektivitas Harian Kendari Pos, Rakyat Sultra dan Berita Kota Kendari dalam memberitakan OTT Walikota Kendari, Adriatma Dwi Putra dan Asrun sekaitan Pilkada Gubernur Sulawesi Tenggara 2018. Penelitian ini dilakukan untuk mengungkapkan Objektivitas Berita Operasi Tangkap Tangan Walikota Kendari Adriatma Dwi Putra dan Asrun di Kendari Pos, Rakyat Sultra dan Berita Kota Kendari. Untuk menambah pengetahuan dan referensi tentang Objektivitas Berita Operasi Tangkap Tangan Walikota Kendari Adriatma Dwi Putra dan Asrun di Harian Kendari Pos, Rakyat Sultra dan Berita Kota Kendari.

Jenis penelitian yang digunakan adalah jenis penelitian deskriptif analitik yang bertujuan menggambarkan dan menganalisa suatu fenomena. Metode yang digunakan yaitu metode analisis isi kuantitatif yang dirumuskan Westertahl. Analisis isi ditujukan untuk mengidentifikasi secara sistematis isi komunikasi yang tampak (manifest), dan dilakukan secara objektif, valid, reliabel, dan dapat direplikasi. (Eriyanto, 2013: 15). Menurut Sugiyono (2010: 208), analisis isi deskriptif bertujuan mendeskripsikan atau menggambarkan data yang telah terkumpul sebagaimana adanya tanpa bermaksud membuat kesimpulan yang berlaku secara umum atau generalisasi. Variabel penelitian adalah segala sesuatu yang berbentuk apa saja yang ditetapkan oleh peneliti untuk dipelajari sehingga diperoleh informasi tentang hal tersebut, kemudian ditarik kesimpulannya. Sugiyono (2010: 60). Variabel yang diteliti dalam penelitian ini adalah variabel-variabel dalam objektivitas Berita Operasi Tangkap Tangan Walikota Kendari Adriatma Dwi Putra dan Asrun.

Populasi dalam penelitian ini adalah berita Operasi Tangkap Tangan (OTT) Walikota Kendari, Adriatma Dwi Putra dan Asrun. Ardial (2015: 336) mengatakan, populasi adalah generalisasi yang terdiri atas objek atau subjek yang mempunyai kuantitas dan karakteristik tertentu yang ditetapkan oleh peneliti untuk dipelajari dan kemudian ditarik kesimpulannya. Teknik penarikan sampel dalam penelitian ini menggunakan teknik pengambilan sampel purposif, yaitu peneliti sengaja memilih sampel periode tertentu atas dasar pertimbangan ilmiah, dalam hal ini berita-berita utama halaman satu edisi tanggal 1,2,3 Maret 2018 yang disiarkan Harian Kendari Pos, Rakyat Sultra, dan Berita Kota Kendari.

Sebelum mengumpulkan data, peneliti membuat lembar koding mengacu konsep objektivitas Westerstahl dengan suratkabar sebagai alat penelusuran data. Data yang terkumpul diberi nilai di lembar koding untuk diolah dan dianalisis. Dalam menganalisis data, peneliti menggunakan data atau nilai yang diberikan pada dimensi faktualitas dan imparsialitas yang diturunkan dalam 11 kolom-kolom indikator yang telah dikelompokkan berdasarkan edisi terbit. Tahap selanjutnya peneliti melakukan interpretasi terhadap data untuk menarik kesimpulan atas temuan penelitian. Nilai yang diberikan antara $1-10$, dimana nilai 1 sangat baik dan 10 sangat buruk. (Eriyanto, 2013: 95). Angka-angka yang diberikan berdasarkan variabel deskrit yang merupakan variabel kategorikal, yaitu variabel yang pemilahannya dilakukan secara kategorikal dengan memperhatikan perbedaan kualitatif berdasarkan klasifikasi dan urutan. (Yusuf, 2016: 105). Sehingga berdasarkan klasifikasi nilai sangat baik berada pada urutan pertama seperti berikut. (1). Sangat baik, (2). Baik (3), 
Sedang (4), Kurang baik , (5). Kurang baik sekali, (6), Kurang buruk sekali, (7). Kurang buruk, (8). Sedang (9), Buruk (10). Sangat buruk Sekali.

Berita yang dimuat di halaman satu suratkabar merupakan realitas sosial yang terjadi dan sedang hangat diperbincangkan masyarakat. Media massa atau suratkabar kemudian menangkap realitas dan mengkonstruksi ulang menjadi teks berdasarkan persepsi peliput, editor dan kebijakan media. Realitas isi teks dan cara penyajiannya dapat dianalisis dengan analisis isi berita. Penelitian tentang analisis isi berita sudah banyak dilakukan dalam kajian yang menyangkut kecenderungan maupun objektivitas pemberitaan suatu media dapat dilihat diantaranya dari paparan peneliti sebelumnya di bawah ini.

Maria dkk (2012) meneliti tentang analisis berita utama suratkabar lokal di Bogor. Analisis isi berita diambil dari Harian Jurnal Bogor dan Radar Bogor, edisi Februari 2012. Penelitian ini bertujuan untuk untuk mengetahui tema-tema berita utama dan nilai berita pada suratkabar Harian Jurnal Bogor dan Radar Bogor edisi 15 Februari hingga 15 Maret 2012. Terdapat tujuh tema-tema berita yang dikaji, yakni (1). Ekonomi dan Keuangan, (2). Politik dan Pemerintahan, (3). Sosial Kemasyarakatan, (4). Hukum dan Kriminal, (5). Olahraga, (6). Pendidikan dan Ilmiah, dan (7). Bencana dan Tragedi. Adapun nilai berita yang dikaji meliputi, (1). Kebaruan, (2). Aktual, (3). Kedekatan, (4). Konflik, dan (5). Ketertarikan Manusiawi. Kesimpulannya, tema utama berita Harian Jurnal Bogor dan Radar Bogor lebih banyak menyajikan tema Bencana dan Tragedi (33\%), dan menggunakan nilai berita Aktual sebagai penentuan layak berita untuk dinaikkan menjadi berita utama.

Made dkk (2011) melakukan penelitian analisis isi liputan berita Universitas Islam Sultan Agung (UNISSULA) Harian Suara Merdeka dan Jawa Pos. Peneliti ingin melihat apakah kedua media bersikap independen dalam memberitakan UNISSULA selama 2011. Peneliti mengacu pada dua kekuatan yang memengaruhi sikap pers pers dalam pemberitaan. Kekuatan pertama berasal dari internal pers itu sendiri, yakni wartawan dan pengelola pers yang menyalahgunakan kekuatan untuk pragmatis sendiri. Kedua dari eksternal (modal, negara, budaya komunalisme) yang menggunakan pers untuk kepentingan sendiri. Penelitian independensi media tersebut dengan melihat jumlah berita, penempatan dan teks. Hasil penelitian menunjukkan di antara 202 berita tentang UNISSULA yang dimuat Suara Merdeka dan 20 di Jawa Pos semuanya bernilai positif. Hasil kajian juga menunjukkan bahwa berita-berita UNISSULA di kedua media sebagian besar adalah berita tentang penyelenggaraan kegiatan UNISSULA dan bersifat straight news. Berita yang bersifat analisa dan hasil reportase mendalam wartawan belum ditemukan. Selain itu, berita tentang UNISSULA di Jawa Pos masih kurang dibanding Suara Merdeka. Bahkan pada bulan tertentu, yakni Februari, September dan Oktober Jawa Pos tidak satu kali pun memberitakan UNISULA.

Rahman dkk (2017) meneliti isi berita politik jelang Pemilukada Serentak 2017 di Harian Kendari Pos dengan mengambil sampel edisi 1 - 31 Oktober 2016. Peneliti mengkaji kecenderungan frekuensi dengan menghitung kolom, baris dan letak headline Pilkada Walikota Kendari, Pilkada Muna Barat dan Pilkada Buton dari keseluruhan berita headline. 
Hasil penelitian menujukkan bahwa dari 137 berita headline, 43 di antaranya berisi berita tentang Pemilukada Serentak Pilkada Walikota Kendari, Pilkada Muna Barat dan Pilkada Buton. Berdasarkan data yang diperoleh, pasangan calon Adriatma Dwi Putra (ADP) dan Sulkarnaen (Sul) lebih banyak disiarkan menjadi berita utama (headline) dengan ruang yang besar dibanding lainnya. Kajian jugamenunjukkan ada kecenderungan keberpihakan media ini kepada pasangan calon ADP-Sul.

\section{PEMBAHASAN}

Penelitian ini menganalisis Objektivitas Berita Operasi Tangkap Tangan Walikota Kendari, Adriatma Dwi Putra dan Asrun oleh Komisi Pemberantasan Korupsi dalam kaitan Pilkada Gubernur Sulawesi Tenggara yang dilaporkan Kendari Pos, Rakyat Sultra, dan Berita Kota Kendari. Peneliti mengkaji objektivitas isi berita dalam 11 , yakni indikator Faktualitas, Akurasi, Lengkap, Normatif, Jurnalistik, Khalayak, Real World, Akses Proporsional, dan Dua Sisi, Non-Evaluatif, dan Non-Sensasional. Masing-masing indikator diberi bobot antara $1-10$.

\section{Tabel 1: Nilai Objektivitas Kendari Pos}

\begin{tabular}{|c|c|c|c|c|c|c|c|c|}
\hline \multirow[t]{2}{*}{ Konsep } & \multirow[t]{2}{*}{ Dimensi } & \multirow[t]{2}{*}{ Subdimensi } & \multirow[t]{2}{*}{ Variabel } & \multirow[t]{2}{*}{ Indikator } & \multicolumn{4}{|c|}{$\begin{array}{l}\text { Nilai (Lembar Koding) } \\
\text { Tanggal }\end{array}$} \\
\hline & & & & & 1 & 2 & 3 & Rerata \\
\hline \multirow[t]{11}{*}{ Objektivitas } & Faktualitas & Truth & Tingkat truth & Faktualitas & 3 & 3 & 2 & 3 \\
\hline & & & dalam berita & Akurasi & 2 & 3 & 2 & 2 \\
\hline & & & & Lengkap & 2 & 4 & 2 & 3 \\
\hline & & Relevansi & Tingkat & Normatif & 2 & 3 & 3 & 3 \\
\hline & & & relevansi dari & Jurnalistik & 2 & 2 & 3 & 2 \\
\hline & & & berita & Khalayak & 5 & 2 & 4 & 4 \\
\hline & & & & Real-world & 2 & 2 & 3 & 2 \\
\hline & Imparsialitas & Berimbang & $\begin{array}{l}\text { Tingkat } \\
\text { keberimbangan }\end{array}$ & $\begin{array}{l}\text { Akses } \\
\text { proporsional }\end{array}$ & 2 & 2 & 3 & 2 \\
\hline & & & berita & Dua sisi & 2 & 2 & 3 & 2 \\
\hline & & Netral & $\begin{array}{l}\text { Tingkat } \\
\text { netralitas berita }\end{array}$ & Non-evaluatif & 5 & 3 & 3 & 4 \\
\hline & & & & $\begin{array}{l}\text { Non- } \\
\text { sensasional }\end{array}$ & 2 & 2 & 3 & 2 \\
\hline
\end{tabular}

Berdasarkan tabel 1 di atas Kendari Pos memiliki nilai objektivitas yang beragam yakni antara nilai 2, 3, 4, dan 5. Pada edisi Kamis, 1 Maret 2018 dengan berita: Pemeriksaan Asrun dan Adriatma Berlanjut di KPK, dan Kasus Hukum Tak Pengaruhi Pencalonan Pilkada, nilai dimensi Faktualitas dan Imparsialitas berturut-turut: Faktualitas: 3, Akurasi: 2, Lengkap: 2, Normatif: 2, Jurnalistik: 2, Khalayak: 5, Real world: 2, Akses proporsional: 2, Dua sisi: 2, Non-evaluatif: 5, dan Non-sensasional: 2.

Pada edisi Kamis, 2 Maret 2018 dengan berita berjudul: Asrun-Adriatma Ditahan Satu Ruangan dan Barang Bukti KPK Hanya Buku Tabungan nilai Faktualitasnya: 3, 
Akurasi: 3, Lengkap: 4, Normatif: 3, Jurnalistik: 2, Khalayak: 2, Real world: 2, Akses proporsional: 2, Dua sisi: 2, Non-evaluatif: 3, dan Non-sensasional: 2. Adapun pada edisi 3 Maret 2018 dengan judul: Adriatma Tetap Walikota Kendari dan Pendukung Asrun Hugua Makin Solid nilai Faktualitasnya: 3, Akurasi: 2, Lengkap: 3, Normatif: 3, Jurnalistik: 2, Khalayak: 4, Real world: 2, Akses proporsional: 2, Dua sisi: 2, Non-evaluatif: 4, dan Nonsensasional: 2. Berdasarkan data tersebut, maka nilai rata-rata tiga edisi Kendari Pos adalah Faktualitas bernilai: 3, Akurasi: 2, Lengkap: 3, Normatif: 3, Jurnalistik: 2, Khalayak: 4, Real world: 2, Akses proporsional: 2, Dua sisi: 2, Non-evaluatif: 4, dan Non-sensasional: 2.

Berdasarkan data tersebut dari hasil rata-rata 11 indikator yang diamati, maka enam indikator memiliki nilai rerata 2 (Baik), yakni indikator Akurasi, Jurnalistik, Real world, Akses proporsional, Dua sisi dan Non-sensasional, sementara tiga lainnya mendapat nilai 3 (Sedang), yakni indikator Faktualitas, Lengkap, Normatif serta dua indikator bernilai 4 (Kurang Baik), yakni Khalayak dan Non-evaluatif.

Tabel 2: Nilai Objektivitas Rakyat Sultra

\begin{tabular}{|c|c|c|c|c|c|c|c|c|}
\hline \multirow[t]{3}{*}{ Konsep } & \multirow[t]{3}{*}{ Dimensi } & \multirow[t]{3}{*}{ Subdimensi } & \multirow[t]{3}{*}{ Variabel } & \multirow[t]{3}{*}{ ndicator } & \multirow{2}{*}{\multicolumn{4}{|c|}{$\begin{array}{l}\text { Nilai (Lembar Koding) } \\
\text { Tanggal }\end{array}$}} \\
\hline & & & & & & & & \\
\hline & & & & & 1 & 2 & 3 & Rerata \\
\hline \multirow[t]{13}{*}{ Objektivitas } & \multirow[t]{7}{*}{ Faktualitas } & \multirow[t]{3}{*}{ Truth } & Tingkat truth & Faktualitas & 3 & 3 & 4 & 3 \\
\hline & & & dalam berita & Akurasi & 2 & 3 & 3 & 3 \\
\hline & & & & Lengkap & 3 & 4 & 4 & 4 \\
\hline & & \multirow[t]{4}{*}{ Relevansi } & Tingkat & Normatif & 2 & 3 & 3 & 3 \\
\hline & & & relevansi dari & Jurnalistik & 2 & 3 & 3 & 3 \\
\hline & & & berita & Khalayak & 2 & 2 & 3 & 2 \\
\hline & & & & Real-world & 2 & 2 & 3 & 2 \\
\hline & \multirow[t]{6}{*}{ Imparsialitas } & \multirow[t]{3}{*}{ Berimbang } & Tingkat & Akses & 3 & 2 & 3 & 3 \\
\hline & & & keberimbangan & proporsional & & & & \\
\hline & & & berita & Dua sisi & 3 & 3 & 3 & 3 \\
\hline & & \multirow[t]{3}{*}{ Netral } & Tingkat & Non-evaluatif & 3 & 3 & 2 & 3 \\
\hline & & & netralitas berita & & & & & \\
\hline & & & & Non-sensasional & 2 & 3 & 2 & 2 \\
\hline
\end{tabular}

Berdasarkan tabel 2 di atas Rakyat Sultra memiliki tiga tingkatan nilai objektivitas, yakni 2, 3, dan 4. Pada edisi Kamis,1 Maret 2018 dengan judul berita: Kedepankan Azas Praduga Tak Bersalah dan KPU Sultra: Pemeriksaan Tak Batalkan Pencalonan, nilai dimensi sebagai berikut: Faktualitas: 3, Akurasi: 2, Lengkap: 3, Normatif: 2, Jurnalistik: 2, Khalayak: 2, Real world: 2, Akses proporsional: 3, Dua sisi: 3, Non-evaluatif: 3, dan Nonsensasional: 2 .

Pada edisi Kamis, 2 Maret 2018 dengan berita berjudul: Ciptakan Kondisi Sultra yang Kondusif, Empat Tersanga Ditahan di Rutan Guntur dan Hari ini Terima Surat Tugas PLT Walikota nilai Faktualitasnya: 3, Akurasi: 3, Lengkap: 4, Normatif: 3, Jurnalistik: 3, 
Khalayak: 2, Real world: 2, Akses proporsional: 2, Dua sisi: 3, Non-evaluatif: 3, dan Nonsensasional: 3 .

Adapun edisi Sabtu, 3 Maret 2018 dengan berita: Jabat PLT, Teguh Minta Sul Tetap Koordinasi dengan ADP, Hugua: Semangat Kami Justru Bertambah, dan KPK Kembali Geledah Sejumlah Tempat di Kendari, nilai Faktualitasnya: 4, Akurasi: 3, Lengkap: 4, Normatif: 3, Jurnalistik: 3, Khalayak: 3, Real world: 3, Akses proporsional: 3, Dua sisi: 3, Non-evaluatif: 2 dan Non-sensasional: 2. Berdasarkan data tersebut, maka nilai rata-rata tiga edisi Rakyat Sultra adalah Faktualitas bernilai: 3, Akurasi: 3, Lengkap: 4, Normatif: 3, Jurnalistik: 3, Khalayak: 2, Real world: 2, Akses proporsional: 3, Dua sisi: 3, Non-evaluatif: 3, dan Non-sensasional: 2.

Berdasarkan data tersebut, dari 11 indikator yang diamati, maka tiga indikator memiliki nilai rerata 2 (Baik), yakni indikator khalayak, real world dan non-sensasional, sementara tujuh indikator mendapat 3 (Sedang), yakni indikator Faktualitas, Akurasi, normatif, jurnalistik, akses proporsional, dua sisi, dan non-evaluatif. Satu lainnya, yakni indikator Lengkap bernilai 4 (Kurang Baik).

\section{Tabel 3: Nilai Objektivitas BKK}

\begin{tabular}{|c|c|c|c|c|c|c|c|c|}
\hline \multirow[t]{2}{*}{ Konsep } & \multirow[t]{2}{*}{ Dimensi } & \multirow[t]{2}{*}{ Subdimensi } & \multirow[t]{2}{*}{ Variabel } & \multirow[t]{2}{*}{ Indikator } & \multicolumn{4}{|c|}{$\begin{array}{l}\text { Nilai (Lembar Koding) } \\
\text { Tanggal }\end{array}$} \\
\hline & & & & & 1 & 2 & 3 & Rerata \\
\hline \multirow[t]{12}{*}{ Objektivitas } & \multirow[t]{7}{*}{ Faktualitas } & \multirow[t]{3}{*}{ Truth } & \multirow{3}{*}{$\begin{array}{l}\text { Tingkat truth } \\
\text { dalam berita }\end{array}$} & Faktualitas & 2 & 2 & 2 & 2 \\
\hline & & & & Akurasi & 2 & 2 & 2 & 2 \\
\hline & & & & Lengkap & 2 & 2 & 2 & 2 \\
\hline & & \multirow[t]{4}{*}{ Relevansi } & \multirow{4}{*}{$\begin{array}{l}\text { Tingkat } \\
\text { relevansi dari } \\
\text { berita }\end{array}$} & Normatif & 2 & 2 & 2 & 2 \\
\hline & & & & Jurnalistik & 2 & 3 & 3 & 3 \\
\hline & & & & Khalayak & 2 & & 3 & 3 \\
\hline & & & & Real-world & 2 & & 3 & 3 \\
\hline & \multirow[t]{5}{*}{ Imparsialitas } & \multirow[t]{3}{*}{ Berimbang } & Tingkat & Akses & & & & \\
\hline & & & keberimbangan & proporsional & 2 & 2 & 3 & 2 \\
\hline & & & berita & Dua sisi & 3 & 2 & 3 & 2 \\
\hline & & \multirow[t]{2}{*}{ Netral } & $\begin{array}{l}\text { Tingkat } \\
\text { netralitas berita }\end{array}$ & $\begin{array}{l}\text { Non- } \\
\text { evaluatif }\end{array}$ & 2 & 3 & 3 & 3 \\
\hline & & & & $\begin{array}{l}\text { Non- } \\
\text { sensasional }\end{array}$ & 3 & 2 & 2 & 2 \\
\hline
\end{tabular}

Berdasarkan tabel 3 di atas Berita Kota Kendari (BKK) memiliki dua tingkatan nilai objektivitas, yakni 2 dan 3 (Baik dan Sedang). Pada edisi Kamis, 1 Maret 2018 dengan berita: Pencalonan Asrun Tetap Sah dan Bisa Dipilih, Rabu Kelabu, Keluarga Asrun, Mendagri Prihatin, Telah Dapat Kode dari KPK, dan Ali Mazi: Beliau Putra Terbaik Sultra. Saya Prihatin. Nilai indikator Faktualitas: 2, Akurasi: 2, Lengkap: 2, Normatif: 2, 
Jurnalistik: 2, Khalayak: 2, Real world: 2, Akses proporsional: 2, Dua sisi: 3, Non-evaluatif: 2, dan Non-sensasional: 3.

Pada edisi Kamis, 2 Maret 2018 berita BKK berjudul: Asrun dan ADP Satu Rutan dengan Nur Alam, DPP tak Bantu Hukum, PJ. Gubernur: Tunggu Pemberitahuan Resmi $K P K$, nilai Faktualitasnya: 2, Akurasi: 2, Lengkap: 2, Normatif: 2, Jurnalistik: 3, Khalayak: 3, Real world: 3, Akses proporsional: 2, Dua sisi: 2, Non-evaluatif: 3, dan Non-sensasional: 2. Adapun pada edisi Sabtu, 3 Maret 2018 dengan judul berita: Waspada! Telusuri Aliran Dana dari Pengusaha lain, KPK Geledah Lima Tempat, dan Optimisme Hugua di Tengah Badai, nilai Faktualitasnya: 2, Akurasi: 2, Lengkap: 2, Normatif: 2, Jurnalistik: 3, Khalayak: 3, Real world: 3, Akses proporsional: 3, Dua sisi: 3, Non-evaluatif: 3 dan Non- sensasional 2. Berdasarkan data tersebut, maka nilai rata-rata tiga edisi Berita Kota Kendari adalah Faktualitas bernilai 2, Akurasi 2, Lengkap: 2, Normatif: 2, Jurnalistik: 3, Khalayak: 3, Real world: 3, Akses proporsional: 2, Dua sisi: 3, Non-evaluatif: 3, dan Non-sensasional: 2.

Berdasarkan data tersebut, dari 11 indikator yang diamati, maka enam indikator memiliki nilai rerata 2 (Baik), yakni indikator Faktualitas, Akurasi, Lengkap, Normatif, Akses proporsional dan Non-evaluatif. Sementara lima indikator mendapat 3 (Sedang), yakni indikator Jurnalistik, Khalayak, Real world, Dua sisi, dan Non-sensasional.

\section{Tabel 4: Nilai Objektivitas Kendari Pos (KP), Rakyat Sultra (RS), Berita Kota Kendari} (BKK)

\begin{tabular}{|c|c|c|c|c|c|c|c|}
\hline \multirow[t]{2}{*}{ Konsep } & \multirow[t]{2}{*}{ Dimensi } & \multirow[t]{2}{*}{ Subdimensi } & \multirow[t]{2}{*}{ Variabel } & \multirow[t]{2}{*}{ Indikator } & \multicolumn{3}{|c|}{$\begin{array}{c}\text { Nilai (Lembar Koding) } \\
\text { MEDIA }\end{array}$} \\
\hline & & & & & $\mathrm{KP}$ & RS & BKK \\
\hline \multirow[t]{12}{*}{ Objektivitas } & Faktualitas & Truth & Tingkat truth & Faktualitas & 3 & 3 & 2 \\
\hline & & & dalam berita & Akurasi & 2 & 3 & 2 \\
\hline & & & & Lengkap & 3 & 4 & 2 \\
\hline & & Relevansi & Tingkat & Normatif & 3 & 3 & 2 \\
\hline & & & relevansi dari & Jurnalistik & 2 & 3 & 3 \\
\hline & & & berita & Khalayak & 4 & 2 & 3 \\
\hline & & & & Real-world & 2 & 2 & 3 \\
\hline & Imparsialitas & Berimbang & Tingkat & Akses & 2 & 3 & 2 \\
\hline & & & keberimbangan & proporsional & & & \\
\hline & & & berita & Dua sisi & 2 & 3 & 2 \\
\hline & & Netral & $\begin{array}{l}\text { Tingkat } \\
\text { netralitas berita }\end{array}$ & Non-evaluatif & 4 & 3 & 3 \\
\hline & & & & Non-sensasional & 2 & 2 & 2 \\
\hline
\end{tabular}

Berdasarkan tabel 4 di atas, dapat dilihat perbedaan dan persamaan nilai indikator ketiga media setelah di rata-ratakan. Kendari Pos memiliki nilai indikator Faktualitas: 3, 
Akurasi: 2, Lengkap: 3, Normatif: 3, Jurnalistik: 2, Khalayak: 4, Real world: 2, Aksesproporsional: 2, Dua sisi: 2, Non-evaluatif: 4, dan Non-sensasional: 2.

Nilai indikator Rakyat Sultra: nilai indikator Faktualitas: 3, Akurasi: 3, Lengkap: 4, Normatif: 3, Jurnalistik: 3, Khalayak: 2, Real world: 2, Akses proporsional: 3, Dua sisi 3, Non-evaluatif: 2, dan Non-sensasional: 2. Adapun nilai rata-rata Berita Kota Kendari: Faktualitas bernilai 2, Akurasi 2, Lengkap: 2, Normatif: 2, Jurnalistik: 3, Khalayak: 3, Real world: 3, Akses proporsional: 2, Dua sisi: 3, Non-evaluatif: 3, dan Non-sensasional: 2

Secara umum hasil penelitian objektivitas ketiga media utama di kota Kendari dalam pemberitaan Operasi Tangkap Tangan Walikota Kendari, Adriatma dan mantan walikota Kendari Asrun memiliki persamaan dan perbedaan. Ada kehati-hatian dalam penyajian berita sehingga berkesan menghimbau atau mengingatkan. Ketiga media tidak menyajikan pendapat masyarakat dan pengamat hukum atau pakar hukum sebagai pengayaan informasi. Namun demikian, sumber berita yang dipilih adalah mereka yang terlibat atau memiliki atribusi yang berkaitan langsung dengan kasus.

Pada pemberitaan tanggal 1 Maret 2018, Kendari Pos cenderung lemah dari relevansi dan netralitas dibanding Rakyat Sultra dan Berita Kota Kendari. Nilai relevansi khalayak: 6 (kurang buruk sekali) dan nilai 5 (kurang baik sekali) pada tingkat netralitas menunjukkan Kendari Pos kurang netral dan cenderung abai terhadap relevansi masyarakat. Sementara pada hari yang sama, nilai khalayak Rakyat Sultra dan BKK: 2, yang berarti baik.

Pada edisi tanggal 2 Maret 2018, Kendari Pos dan Rakyat Sultra sama-sama mendapat nilai 4 (kurang baik) pada indikator lengkap, sementara indikator lain mendapat nilai 2 dan 3. Adapun pada indikator lengkap Berita Kota Kendari pada edisi yang sama bernilai 2 (baik) yang berarti liputan BKK lebih banyak menampilkan fakta empiris dan fakta psikologis dengan mewawancarai banyak pihak.

Penyajian berita pada edisi 3 Maret 2018 ditemukan nilai 4 (kurang baik) pada indikator khalayak di Kendari Pos, serta nilai 4 pada indikator faktualitas dan indikator lengkap. Kurang baik pada indikator khalayak menunjukkan hubungan isi berita dengan kebutuhan informasi khalayak kurang terpenuhi, sementara nilai 4 (kurang baik) pada faktualitas dan lengkap menunjukkan penyajian Rakyat Sultra pada hari itu lemah dari segi liputan narasumber dan pemisahan fakta dan opini, komentar dan interpretasi.

Pada penelitian ini, indikator nilai rata-rata Kendari Pos ditemukan nilai 4 (kurang baik) pada dua indikator, yakni indikator khalayak dan non evaluatif, yang berarti berita yang disajikan cenderung memberikaan penilaian dan kurang memberi ruang kepada masyarakat untuk berkontribusi pendapat. Nilai indikator lainnya berada pada kisaran 2 dan 3 yang berarti baik dan sedang. Secara keseluruhan dari 11 indikator yang diteliti, komposisi nilai objektivitas Kendari Pos adalah enam yang baik, tiga yang sedang dan dua yang kurang baik. 
Berbeda dengan Rakyat Sultra yang mendapat nilai 4 pada indikator lengkap, sehingga dapat dikatakan penyajian beritanya terasa belum memuat sejumlah fakta yang ada, seperti bagaimana kedekatan para tersangka. Nilai objektivitas Rakyat Sultra adalah tiga yang baik, tujuh yang sedang dan satu yang kurang. Sementara nilai objektivitas Berita Kota Kendari terdiri tujuh bernilai dan empat bernilai sedang.

\section{PENUTUP}

Berdasarkan hasil penelitian, kesimpulan yang ditarik adalah terdapat persamaan dan perbedaan nilai objektivitas Kendari Pos, Rakyat Sultra dan Berita Kota Kendari. Ketiga media sama-sama menyajikan berita tanpa melebih-lebihkan fakta di lapangan, sementara Kendari Pos cenderung memberi penilaian atau menjustifikasi berita sehingga relevansi berita dengan keingintahuan masyarakat rendah. Adapun Rakyat Sultra belum maksimal menghadirkan fakta-fakta atau peristiwa dalam berita OTT ini. Sedangkan nilai objektivitas Berita Kota Kendari berada di atas keduanya, serta menyiarkan berita lebih banyak, yakni 10, Rakyat Sultra delapan berita dan Kendari Pos enam berita. Hanya Berita Kota Kendari yang menyertakan data grafis. Meski ada perbedaan dan persamaan, objektivitas ketiga media yang diteliti masih baik dengan nilai Sedang.

Setelah melihat hasil penelitian, maka disarankan agar ketiga media tetap melakukan kerjasama dan hubungan profesional dengan pemerintah, birokrat, politisi dan pengusaha, namun tetap menjaga jarak agar tidak ada intervensi yang bisa memengaruhi objektivitas pemberitaan. Membuat infografis proses penangkapan secara detai serta info-info tentang latar peristiwa dan latar belakang para tersangka.

\section{DAFTAR PUSTAKA}

Ardial. 2015. Paradigma dan Model Penelitian Komunikasi. Jakarta. PT. Bumi Aksara Arifin, Anwar.2010. Pers dan Dinamika Politik. Jakarta: Yarsif Watampone

Dwi Adnjani Made, Mubarok.2011. Analisis Isi Pemberitaan Tentang UNISSULA di Media Cetak (Analisis Isi Pembweritaan Harian Suara Merdeka dan Jawa Pos)

Eriyanto. 2013. Analisis Isi. Jakarta. Prenada Media Group.

Fitriah Maria, El'Arsya Fadlya. 2012. Berita Utama Surat Kabar Lokal Bogor. (Studi Analisis Isi pada Jurnal Bogor dan Radar Bogor, edisi 15 Februari - 15 Maret 2012)

Cahya, Inung S. 2012. Menulis Berita di Media Massa. Yoyakarta. PT. Citra Aji Parama.

Yusuf . 2016. Metode Penelitian Kuantitatif, Kualitatif \& Penelitian Gabungan. Jakarta. Prenadamedia Group.

Mondry. 2008. Pemahaman Teori dan Praktik Kurnalistik. Bogor. Ghalia Indonesia Sugiyono. 2010. Metode Penelitian Pendidikan. Bandung. Alfabeta Bandung

Takdir Rahman, dkk 2017. Analisis Isi Berita Politik Jelang Pemilukada Serentak Tahun 2017 Di Harian Kendari Pos (Studi Headline Edisi 1 - 31 Oktober 2016) 